\title{
Growth hormone receptors in ovary and liver during gametogenesis in female rainbow trout (Oncorhynchus mykiss)
}

\author{
J. M. Gomez, B. Mourot, A. Fostier and F. Le Gac* \\ Laboratoire de Physiologie des Poissons, INRA, Campus de Beaulieu, 35042 Rennes Cedex, France
}

\begin{abstract}
Changes of growth hormone receptivity in the ovary during the reproductive cycle were studied in rainbow trout (Oncorhynchus mykiss). A method for characterizing growth hormone receptors in crude ovary homogenate was required for this. Binding of radiolabelled recombinant rainbow trout growth hormone ( ${ }^{125} \mathrm{I}$-labelled $\mathrm{rtGH}$ ) to crude ovary preparation was dependent on ovarian tissue concentration. The sites were specific to growth hormone, with no affinity for prolactins and gonadotrophins. Similar high affinities for ${ }^{125} \mathrm{I}$-labelled $\mathrm{rtGH}$ were obtained with crude ovary $\left(4.2 \times 10^{9} \pm 0.3 \mathrm{~mol}\right.$ $\left.\mathrm{l}^{-1}\right)$ and crude liver preparations $\left(4.9 \times 10^{9} \pm 0.1 \mathrm{~mol}^{-1}\right)$ at all stages of ovogenesis, and with ovarian membrane preparations $\left(8.2 \times 10^{9} \mathrm{moll}^{-1}\right)$ tested at the beginning of vitellogenesis. Ovarian growth hormone receptor concentration was highest during the early phases of follicular development (endogenous vitellogenesis: $315-310 \mathrm{fmol} \mathrm{g}^{-1}$ ovary) and decreased regularly during oocyte and follicular growth (exogenous vitellogenesis) to reach a minimal value at oocyte maturation ( $42 \mathrm{fmol} \mathrm{g}^{-1}$ ovary). In postovulated fish, binding was at a similar level ( $297 \mathrm{fmol} \mathrm{g}^{-1}$ ovary) to that found in endogenous vitellogenesis. Conversely, the absolute binding capacity of the whole ovary was low from immaturity to early exogenous vitellogenesis $(0.1-0.6$ pmol per pair of gonads), increased slowly during vitellogenesis and more markedly during rapid oocyte growth and at the time of final maturation (10.8 pmol per pair of gonads). In postovulated fish, the absolute binding capacity decreased partially $(4.4$ pmol per pair of gonads). Mean hepatic growth hormone receptor concentration did not vary with the reproductive stage for most of the cycle (3.0-4.5 pmol g-1 liver) except in endogenous vitellogenesis where significantly higher concentrations were observed $\left(6.7 \mathrm{pmol} \mathrm{g}^{-1}\right.$ liver). Individual ovarian growth hormone receptor concentrations were correlated with hepatic growth hormone receptor concentrations, indicating that they are regulated in a similar way. We conclude that growth hormone receptors are present in the ovary during the entire ovarian cycle in rainbow trout, probably mainly in somatic cells as indicated by the same concentration of binding sites in immature and in postovulated fish. Growth hormone is potentially important during oocyte recruitment in vitellogenesis and initiation of growth and during final follicular maturation.
\end{abstract}

\section{Introduction}

Although gonadotrophins are the major regulators of ovarian function in vertebrates, accumulating evidence indicates a role for growth hormone $(\mathrm{GH})$ in the control of the female reproductive process (for review, see Adashi $e t$ al., 1992; Katz et al., 1993; Le Gac et al., 1993). Delayed pubertal development in human and animal isolated GH deficiency can be restored by GH treatment (Sheikholislam and Stempfel, 1972; Ramaley and Phares, 1980; Advis et al., 1981; Ovesen et al., 1992), and GH therapy has been used with success as an adjuvant to gonadotrophin for ovulation induction in assisted human reproduction (Volpe et al., 1989;

*Correspondence.

Received 17 April 1998.
Homburg et al., 1990; Burger et al., 1991; Jacobs et al., 1991). Direct effects of GH on the ovary were proposed after the first in vitro studies had demonstrated that GH stimulates granulosa cell differentiation of murine (Jia et al., 1986; Hutchinson et al., 1988), pig (Hsu and Hammond, 1987) and human (Mason et al., 1990) ovarian follicles. A large body of evidence indicates that GH effects may be mediated, in part, through an intra-ovarian insulin-like growth factor (IGF) system (for review, see Adashi et al., 1992; Guidice, 1992). The detection of low GH receptor and/or binding protein (GH-R/BP) mRNA in rat (Tiong and Herington, 1991; Bingham et al., 1994), rabbit (Ymer and Herington, 1992) and human (Mercado et al., 1994) ovaries also indicated a direct action for GH. Attempts to localize ovarian cells carrying GH-R have revealed some discrepancies. Expression of mRNA encoding GH-R/BP and GH-R/BP immunoreactivity 
were widespread in the rat ovary (Lobie et al., 1990), mainly in granulosa and theca cells (human: Mertani et al., 1995) and localized in the granulosa cells of preantral and antral follicles (rat: Carlsson et al., 1993; sheep: Eckery et al., 1997), in the granulosa cells of dominant follicles and luteal cells (humans: Sharara and Nieman, 1994; Tamura et al., 1994) or in luteal cells (cattle and pigs: Lucy et al., 1993; Yuan and Lucy, 1996). Finally, expression of GH-R/BP mRNA was low in ovine and bovine oocytes (Eckery et al., 1997; Izadyar et al., 1997). Binding studies reported the possible occurrence of functional GH receptors in human and rabbit ovary (Carlsson et al., 1992; Ando et al., 1994), and both experiments used human GH which reacts with the lactogenic receptor as well as (or even better than) the somatogenic receptor. In fact, most attempts have been unsuccessful in demonstrating and quantifying GH receptors in mammalian ovarian tissues by binding assays (Webb et al., 1994; Eckery et al., 1997), due to high non-specific binding.

In teleost fish, the presence of binding sites for homologous GH has been detected in ovary (Yao et al., 1991; Gray et al., 1990), and Mourot et al. (1992) have described $\mathrm{GH}$-specific binding with general characteristics of GH-R in rainbow trout ovarian membrane preparations. These GH-R appear functional in teleost fish, as GH treatments are able to modify the gonadal production of sexual steroids in vivo and in vitro (Singh et al., 1988; Van Der Kraak et al., 1990; Le Gac et al., 1992; Singh and Thomas, 1993).

In rainbow trout, the ovogenesis and ovulation of thousands of gametes occur synchronously in the entire ovary, providing a particularly convenient model in which to study physiological changes during successive stages of folliculogenesis and oocyte maturation.

In the present study, changes in gonadal GH-R concentration during the initial ovarian cycle in rainbow trout were studied to investigate the role of GH in gonadal development during puberty, follicular and oocyte growth, and final maturation. First, it was necessary to characterize the specific binding of GH to crude ovarian preparation and to validate this method to allow quantitative studies in individual and small gonads. Changes in ovarian GH-R concentration during the reproductive cycle were analysed in relation to plasma GH concentrations and in comparison with hepatic GH-R contents during the same period.

\section{Materials and Methods}

\section{Animals}

One-year-old female rainbow trout (Oncorhynchus mykiss) of the Cornec Autumnal strain (fall spawning) reared at the INRA experimental fish farm (Sizun, Finistère, France) were used. During the entire experimental period (January 1995-November 1995), fish were kept under natural temperature conditions (February: $8.5^{\circ} \mathrm{C}$; August: $20^{\circ} \mathrm{C}$ ) and photoperiod $\left(48^{\circ} \mathrm{N}\right.$ ) in circulating fresh water tanks (capacity $1800 \mathrm{l}$ ), and fed once per day for 6 days per week (except for 2 days before sampling) with commercial pellets (Aqualife number 17, Aqualim SA, St Estephe, France) at the rate recommended by the manufacturer.

\section{Experimental design}

This study was designed to investigate the changes in ovarian GH-R during one ovogenetic cycle. Approximately once per month, 35-45 females (sexually immature, $546 \pm 19 \mathrm{~g}$ body weight in January; sexually mature, $2200 \pm 170$ g body weight in November) randomly caught were killed ( $n=11$ samplings). At each sampling, after rapid anaesthesia (3-4 min) in phenoxy-2-ethanol $\left(0.5 \mathrm{ml} \mathrm{l}^{-1}\right)$ the body weight $( \pm 1 \mathrm{~g})$ and length $( \pm 0.1 \mathrm{~cm})$ of each female were measured. Blood samples were collected rapidly from the caudal vasculature in heparinized syringes. The samples were then centrifuged $\left(4^{\circ} \mathrm{C}\right)$ at $3200 \mathrm{~g}$ for $20 \mathrm{~min}$, and the plasma was stored in aliquots at $-20^{\circ} \mathrm{C}$ until assayed. Ovary and liver were dissected out, weighed to determine gonadosomatic index (GSI $=$ ovarian mass $\times 100 /$ body weight $)$ and hepatosomatic index (HSI = liver mass $\times 100 /$ body weight), and then frozen individually in liquid nitrogen, and stored at $-70^{\circ} \mathrm{C}$ until used.

Transverse sections from the middle part of the ovaries were fixed in Bouin's solution for histological examination. The ovarian stage of each fish was determined by histological examination for early stages (oocytes with diameter $<1 \mathrm{~mm}$ ) and by GSI measurements as described by Breton et al. (1983), and by macroscopic observation for oocyte maturation (Jalabert, 1976). The stages were defined as: stage 1: previtellogenic ovary containing oogonia and primary oocytes; stages 2 and 3: early and advanced endogenous or type I vitellogenesis; stages 4.1 to 5 : subclasses of exogenous or type II vitellogenesis based on the increasing proportion of oocytes containing vitellus deposit in yolk globules and platelets (4.1 and 4.2) and on increasing GSI which was found directly proportional to the oocyte diameter in stages 4.2 to 5 (in this particular cohort, vitellogenesis continued until close to final maturation); stage 5: preovulatory stage with macroscopic signs of oocyte final maturation; stage 6: post-ovulatory stage. 'Previtellogenic' oocytes remained observable in the gonad, although in decreasing number, at least until stage 4.2 (Table 1)

\section{Hormones}

Recombinant rainbow trout $\mathrm{GH}(\mathrm{rtGH})$ and recombinant tilapia GH (rtiGH; Rentier-Delrue et al., 1989) were generously provided by J. Smal (Eurogentec, Liège) and F. Rentier-Delrue, respectively. The mammalian hormone preparations were pituitary-extracted bovine GH (batch bGH-B-1, NIDDK, NIH, Bethesda, MD) and pituitaryextracted ovine prolactin (batch oPRL-19, NIDDK, NIH). Trout gonadotrophins (tGTH I and tGTH II; Govoroun et al., 1997) and salmon prolactin (sPRL; Prunet and Houdebine, 1984) were purified in our laboratory.

Five micrograms $\mathrm{rtGH}$ was radiolabelled with $0.5 \mathrm{mCi}$ $\mathrm{Na}^{125}$ I (IMS 30, Amersham, Les Ulis, France) by the chloramine-T method (Greenwood et al., 1963), with the modification introduced by Martal (1972). The specific activity of ${ }^{125} \mathrm{I}$-labelled $\mathrm{rtGH}$, measured by self displacement on hepatic membrane preparation ( $5 \mathrm{mg}$ pellet per tube) was

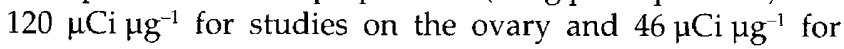


Table 1. Ovarian stages of rainbow trout defined on the basis of oocyte histological and macroscopic characteristics and on gonadosomatic index (GSI)

\begin{tabular}{|c|c|c|}
\hline Stages & Characteristics & GSI \\
\hline $\begin{array}{l}\text { 1. Immature } \\
\text { (previtellogenesis) }\end{array}$ & Previtellogenic oocytes + rare oocytes with cortical alveoli & $0.1 \pm 0.004$ \\
\hline $\begin{array}{l}\text { 2. Early endogenous } \\
\text { vitellogenesis }\end{array}$ & Previtellogenic $+25 \%$ oocytes with cortical alveoli & $0.1 \pm 0.01$ \\
\hline $\begin{array}{l}\text { 3. Endogenous } \\
\text { vitellogenesis }\end{array}$ & Tissue consists mainly of oocytes with cortical alveoli and lipidic globules & $0.2 \pm 0.02$ \\
\hline $\begin{array}{l}\text { 4.1. Early exogenous } \\
\text { vitellogenesis }\end{array}$ & Scarce oocytes with yolk globules & $0.4 \pm 0.02$ \\
\hline $\begin{array}{l}\text { 4.2. Mid-exogenous } \\
\text { vitellogenesis }\end{array}$ & All maturing oocytes with lipidic globules & $0.7 \pm 0.04$ \\
\hline $\begin{array}{l}\text { 4.3. Advanced exogenous } \\
\text { vitellogenesis }\end{array}$ & Plus increasing number of yolk globules & $4.3 \pm 0.4$ \\
\hline $\begin{array}{l}\text { 5. Final maturation } \\
\text { (pre-ovulation) }\end{array}$ & From germinal vesicle migration to oocyte periphery to germinal vesicle breakdown & $13.1 \pm 0.5$ \\
\hline 6. Postovulation & 1 day to 4 weeks after ovulation & $0.7 \pm 0.05$ \\
\hline
\end{tabular}

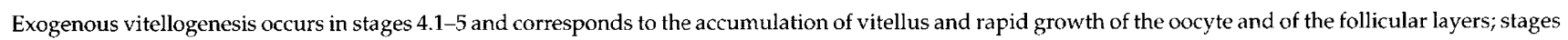

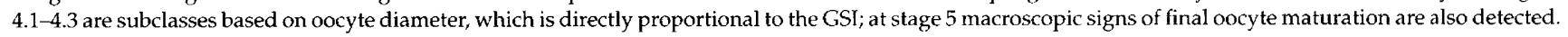

studies on the liver. The maximum binding activity (MBA) of ${ }^{125} \mathrm{I}$-labelled $\mathrm{rtGH}$, estimated with an excess amount of liver membrane preparation, ranged from 60 to $65 \%$ of total added hormone. The labelled hormone was stable for about 3 weeks when stored in glycerol $(1 / 1, \mathrm{v} / \mathrm{v})$ at $-20^{\circ} \mathrm{C}$. Radioactivity was measured in a $\gamma$-counter (Packard Instrument Co., Meriden, CT) with a counting efficiency of $75 \%$.

\section{Tissue preparations}

Crude ovarian fractions were obtained at $0-4^{\circ} \mathrm{C}$ using chilled buffers according to the following method. Ovaries were minced and homogenized with a Polytron homogenizer $(2 \times 15$ s, 8000 r.p.m.) in ice-cold homogenization buffer $(1: 5 \mathrm{w} / \mathrm{v})\left(20 \mathrm{mmol}\right.$ Tris- $\mathrm{HCl} \mathrm{l}{ }^{-1} \mathrm{pH} \mathrm{7.5,5} \mathrm{mmol} \mathrm{MgCl}_{2} \mathrm{l}^{-1}$, $\left.5 \mathrm{mmol} \mathrm{CaCl}_{2} \mathrm{l}^{-1}, 0.1 \%(\mathrm{w} / \mathrm{v}) \mathrm{NaN}_{3}\right)$, complemented with para-aminobenzamidine $\left(0.25 \mathrm{mg} \mathrm{ml}^{-1}\right), 4$-(2-aminoethyl)benzenesulfonyl fluoride $\left(0.1 \mathrm{mg} \mathrm{ml}^{-1}\right)$ and soya bean trypsin inhibitors $\left(0.05 \mathrm{mg} \mathrm{ml}^{-1}\right)$. Gonads were crushed and washed twice in homogenization buffer before being processed to eliminate yolk in vitellogenic and mature ovaries. The preparation was further homogenized by passing through a Dounce homogenizer and centrifuged at $3200 \mathrm{~g}$ for $30 \mathrm{~min}$. The pellet was then washed in 5 volumes of buffer and centrifuged at $3200 \mathrm{~g}$ for $30 \mathrm{~min}$. The supernatant was removed and the final pellet, which contained membrane fractions of all ovarian cell types (stages 1-5) or no more oocyte membranes (stage 6), was weighed and resuspended in ice-cold incubation buffer (homogenization buffer containing soya bean trypsin inhibitors $0.05 \mathrm{mg} \mathrm{ml}^{-1}$ and $0.5 \%(\mathrm{w} / \mathrm{v}) \mathrm{BSA})$.

Ovarian membrane preparations were obtained as described by Mourot et al. (1992). Briefly, ovaries were homogenized in 5 mmol Tris- $\mathrm{HCl} \mathrm{l}^{-1} \mathrm{pH} 7.2,100 \mathrm{mmol} \mathrm{NaCl}$ $\mathrm{l}^{-1}, 5 \mathrm{mmol} \mathrm{CaCl}_{2} \mathrm{l}^{-1}, 100 \mathrm{mmol}$ sucrose $\mathrm{l}^{-1}$ containing inhibitors of proteolytic enzymes $(1 / 5, \mathrm{w} / \mathrm{v})$, and centrifuged at $600 \mathrm{~g}$ for $20 \mathrm{~min}$. The supernatant was recentrifuged at
$30000 \mathrm{~g}$ for $45 \mathrm{~min}$ and the resulting pellet was resuspended as described above. Crude hepatic preparations were obtained according to the method of Yao et al. (1991). All preparations were used immediately in the binding assay.

\section{Binding assay}

Three hundred microlitres of crude ovary homogenate corresponding to 20 or $30 \mathrm{mg}$ pellet per tube (approximately 2 or $3 \mathrm{mg}$ of protein per tube, depending on the stage of ovogenesis) were added to $12 \times 75 \mathrm{~mm}$ polystyrene tubes containing $100 \mu \mathrm{l}{ }^{125}$ I-labelled rtGH (saturation studies: increasing amounts ranged from 30000 to 1200000 c.p.m. per tube, equivalent to $13-520 \mathrm{pmol} \mathrm{1}^{-1}$; single point binding studies: 300000 c.p.m. per tube, equivalent to $130 \mathrm{pmol} \mathrm{1}^{-1}$ ), with (non-specific binding, NSB) or without (total binding, TB) unlabelled $\mathrm{rtGH}$ (500 ng per tube) in a final volume of $500 \mu \mathrm{l}$. Incubation was carried out at $12^{\circ} \mathrm{C}$ for $20 \mathrm{~h}$, under gentle agitation (120 strokes $\mathrm{min}^{-1}$ ) and was terminated by the addition of $3 \mathrm{ml}$ ice-cold incubation buffer followed by centrifugation at $3200 \mathrm{~g}$ for $30 \mathrm{~min}$. The supernatants were discarded and the radioactivity in the pellet was counted. The binding assay with other preparations was performed as described above with $50 \mathrm{mg}$ pellet per tube for ovary membrane preparations, and $5 \mathrm{mg}$ pellet per tube for crude hepatic preparation. Specific binding per $\mathrm{mg}$ of pellet or $\mathrm{mg}$ of protein was calculated by subtracting NSB from the TB. Since GH-specific binding to crude ovary preparations were low, all binding measurements were performed in quadruplicate.

\section{Other assays}

The protein concentration in the final (ovary and liver) preparations was determined in duplicate by the bicinchoninic acid method (BCA protein assay reagent, 
Pierce, Rockford, IL), with bovine serum albumin (BSA) as a standard. The amount of plasma GH was determined using a homologous radioimmunoassay developed in our laboratory (Le Bail et al., 1991). The sensitivity of the assay (ED 90) was $0.2 \mathrm{ng} \mathrm{ml}^{-1}$ for $50 \mu \mathrm{l}$ assayed plasma and the $\mathrm{ED}_{50}$ value was $1.0 \mathrm{ng} \mathrm{ml}^{-1}$.

\section{Data analysis}

For each ovogenetic stage, affinity constants $\left(K_{a}\right)$ and binding capacities $\left(B_{\max }\right)$ were calculated according to the method of Scatchard (1949). Scatchard plot analyses were performed with free $(U)$ hormone values corrected for MBA. Scatchard plots were compared using covariance analysis. The statistical difference among groups was analysed by one-way analysis of variance (ANOVA) followed by multiple range test (Kruskal-Wallis test; differences were considered significant when $P<0.05$ ). Linear regression analysis was used to detect the relationships among variables. All results are expressed as mean \pm SEM.

Ovary and liver size change with sexual development and also with body growth. The total GH receptor capacity was expressed in pmol per organ and compared with the same parameter normalized for body weight (pmoles per liver $\mathrm{kg}^{-1}$ body weight) with a view to analysing changes specifically linked to the reproductive stage.

\section{Results}

\section{Characterization of ovarian growth hormone binding sites}

The specific binding of ${ }^{125}$ I-labelled rtGH to increasing amounts of crude ovarian preparation obtained at the beginning of exogenous vitellogenesis (Fig. 1) and in the immature stage (data not shown) was dependent on a membrane concentration in the range of 10 to $50 \mathrm{mg}$ pellet per tube (approximately $1-5 \mathrm{mg}$ of protein per tube). In the following experiments $20 \mathrm{mg}$ pellet per tube was used for quantitative studies (single point binding), and 20 or $30 \mathrm{mg}$ pellet per tube was used for saturation experiments (depending on the stage of ovogenesis).

${ }^{125}$-labelled $\mathrm{rtGH}$-specific binding appeared saturable when increasing concentrations of ${ }^{125}$ I-labelled $\mathrm{rtGH}$ were incubated with a fixed amount of ovarian preparation (Fig. 2a). Scatchard plot analyses were linear, indicating the presence of a single population of binding sites with high affinity $\left(K_{\mathrm{a}}=4.2 \pm 0.3 \times 10^{9} \mathrm{~mol}^{-1}, n=17\right)$ and a limited number of sites. The affinity constants in crude ovary preparations were of the same order of magnitude as those observed both in ovary membrane preparations (Fig. 2b) and in crude liver preparations (Fig. 2c).

The specificity of GH binding sites to crude ovarian preparation was tested in competition experiments (Fig. 3). Unlabelled $\mathrm{rtGH}$ at concentrations of $0.1-250 \mathrm{ng}$ per tube progressively inhibited the specific binding of the tracer. Bovine $\mathrm{GH}$ and rtiGH competed with ${ }^{125} \mathrm{I}$-labelled $\mathrm{rtGH}$ in a dose-dependent manner but appeared to be 30 and 100 times less effective (calculated at $50 \%$ displacement) than

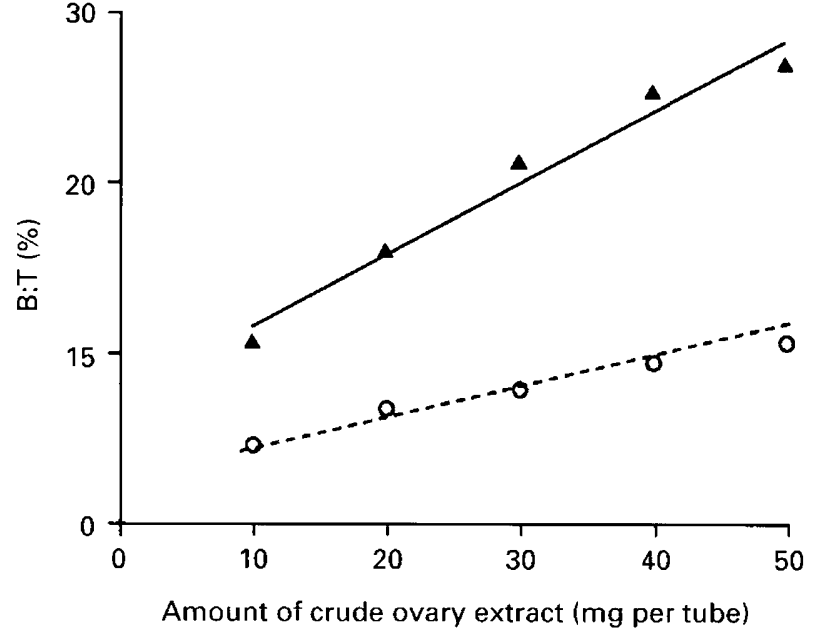

Fig. 1. Specific binding (---) and non-specific binding $(-)$ of ${ }^{125} \mathrm{I}-$ labelled recombinant trout $\mathrm{GH}$ to increasing amounts of crude ovarian preparation obtained from a pool of gonads at stage 4.2 of ovogenesis. $\mathrm{B}$, fraction of hormone bound; $\mathrm{T}$, total added hormone in the incubate.

unlabelled $\mathrm{rtGH}$, respectively. Salmon prolactin, ovine prolactin and trout gonadotrophins (GTH I, GTH II) did not significantly compete with ${ }^{125}$ I-labelled rtGH for the binding sites at the tested concentrations.

\section{Changes of gonadosomatic index and hepatosomatic index during ovogenesis}

In these autumnal spawning rainbow trout, after 1 year of prepubertal immaturity, vitellogenesis developed more or less synchronously in the whole gonad from March-April, as indicated by the presence of vitellogenic follicles (stage 2) to September-October (ovulation). The definition and characteristics of the ovarian stages used are presented (Table 1). In this population, the gonadosomatic index remained low in the early stages until July (early endogenous vitellogenesis through advanced exogenous vitellogenesis) and increased markedly at the end of exogenous vitellogenesis to reach maximum values during final maturation (Fig. 4a). The hepatosomatic index also increased at the end of vitellogenesis and appeared significantly higher $(P<0.001)$ before ovulation (Fig. 4 b). In the present experiment, the whole experimental trout population matured.

\section{Changes in ovarian growth hormone receptors during ovogenesis}

Saturation experiments were conducted at each stage of ovogenesis (1-4 experiments per stage) on pools of ovaries at the same histological stage (Table 2). Scatchard plots revealed that affinity constants were of the same order of magnitude (covariance analysis) during the entire cycle $\left(4.2 \times 10^{9} \pm 0.3 \mathrm{~mol} \mathrm{l}^{-1}, n=17\right)$, while binding capacities $\left(B_{\max }\right)$ showed significant changes. 

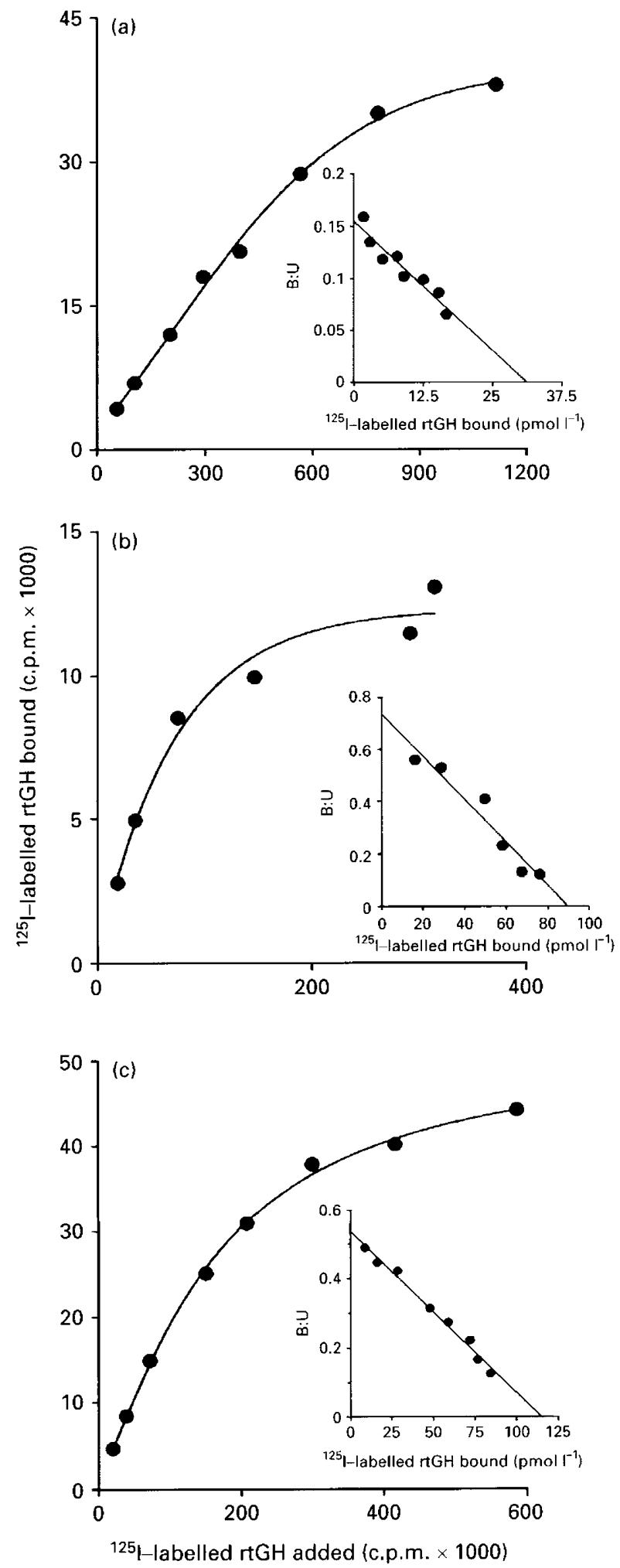

Fig. 2. Effect of increasing concentrations of ${ }^{125}$ I-labelled recombinant trout GH (rtGH) (30000-1200000 c.p.m. per tube) on specific binding to (a) crude ovarian preparation ( 20 or $30 \mathrm{mg}$ pellet per tube; $\left.K_{a}=4.9 \times 10^{9} \mathrm{~mol} \mathrm{l}^{-1} ; \quad B_{\text {max }}=31 \mathrm{pmol} \mathrm{l}^{-1}\right)$, (b) ovary membrane preparation (50 mg pellet per tube; $K_{\mathrm{a}}=8.2 \times 10^{9} \mathrm{~mol} \mathrm{l}^{-1}$; $\left.B_{\max }=89 \mathrm{pmol}^{-1}\right)$, (c) crude liver preparation ( $5 \mathrm{mg}$ pellet per tube; $\left.K_{\mathrm{a}}=4.7 \times 10^{9} \mathrm{~mol} \mathrm{l}^{-1} ; B_{\max }=115 \mathrm{pmol} \mathrm{l}^{-1}\right)$. The insets represent the

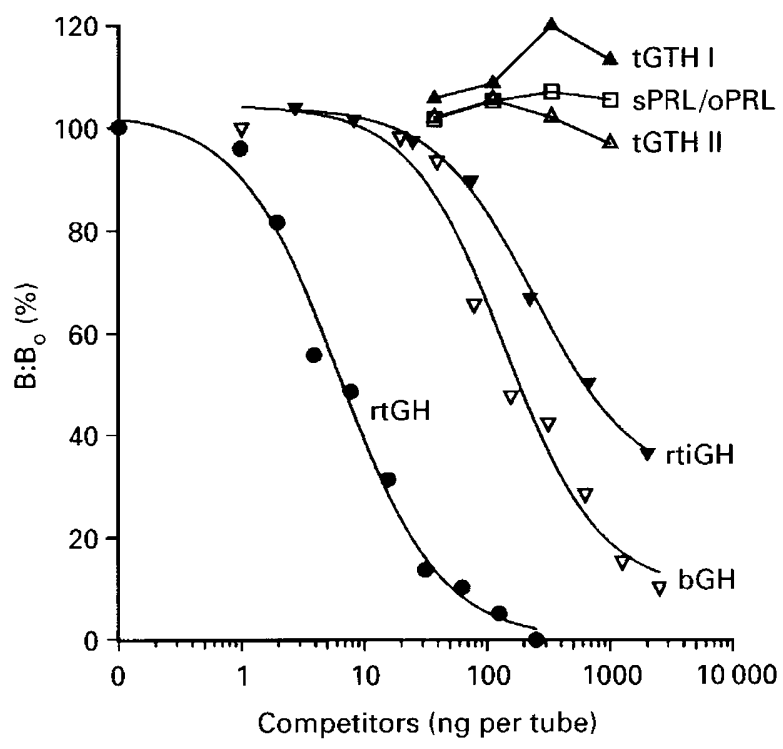

Fig. 3. Competition curves for specific binding of ${ }^{125} \mathrm{I}$-labelled recombinant trout $\mathrm{GH}$ ( $\mathrm{rtGH}$ ) (30000 c.p.m. per tube) to crude ovarian preparation ( $40 \mathrm{mg}$ pellet per tube, stage 3 of ovogenesis) with increasing amounts of unlabelled hormone preparations. Binding is expressed as a percentage of ${ }^{125} \mathrm{I}$-labelled $\mathrm{rtGH}$ specifically bound in the absence of competitor. $\mathrm{rtiGH}$, recombinant tilapia $\mathrm{GH}$; bGH, bovine $\mathrm{GH}$; sPRL, salmon prolactin; oPRL, ovine prolactin; tGTH I, tGTH II, trout gonadotrophins.

Since the equilibrium association constant at each stage of ovogenesis was found to be similar, binding studies with only $50 \%$ of the saturating concentration of ${ }^{125}$ I-labelled rtGH were carried out to work with the small amounts of tissue and to estimate changes of $\mathrm{GH}$ receptors in a large number of individual ovaries. Specific binding of ${ }^{125} \mathrm{I}$-labelled $\mathrm{rtGH}$ was measured on 40 individual ovaries at different stages of ovogenesis (except for immature stage ovaries and those with oocytes at the final stage of maturation, where pools of gonads were used) (Fig. 5a). The results show that binding was highest during endogenous vitellogenesis (315-310 fmol $\mathrm{g}^{-1}$ ovary) and decreased regularly $(P<0.001)$ during the entire exogenous vitellogenesis to reach a minimal value during oocyte maturation ( $42 \mathrm{fmol} \mathrm{g}^{-1}$ ovary). In postovulated fish, binding was similar ( $297 \mathrm{fmol} \mathrm{g}^{-1}$ ovary) to that of fish in endogenous vitellogenesis. The binding tended to change similarly when the results were expressed in fmol $\mathrm{mg}^{-1}$ protein: the highest amount of binding occurring during endogenous vitellogenesis $\quad\left(230-235 \mathrm{fmol} \mathrm{mg}^{-1}\right.$ protein) and in postovulated fish (231 $\mathrm{fmol} \mathrm{mg}^{-1}$ protein), and the lowest amount (60 fmol $\mathrm{mg}^{-1}$ protein) occurring at oocyte maturation. These results were in good agreement with data obtained in the saturation experiments (Table 1). A different pattern was observed when the data were expressed in fmol $\mathrm{g}^{-1}$ pellet (Fig. $5 \mathrm{~b}$ ). During the first stages, the binding was high and increased significantly from stages 1 to 3 (690$1110 \mathrm{fmol} \mathrm{g}^{-1}$ pellet $)$, decreased $(P<0.001)$ in stage 4.1 to stay

derived Scatchard plots. Scatchard plot analyses were performed with values for free (U) hormone corrected for maximum binding activity of the tracer. B, fraction of hormone bound. 

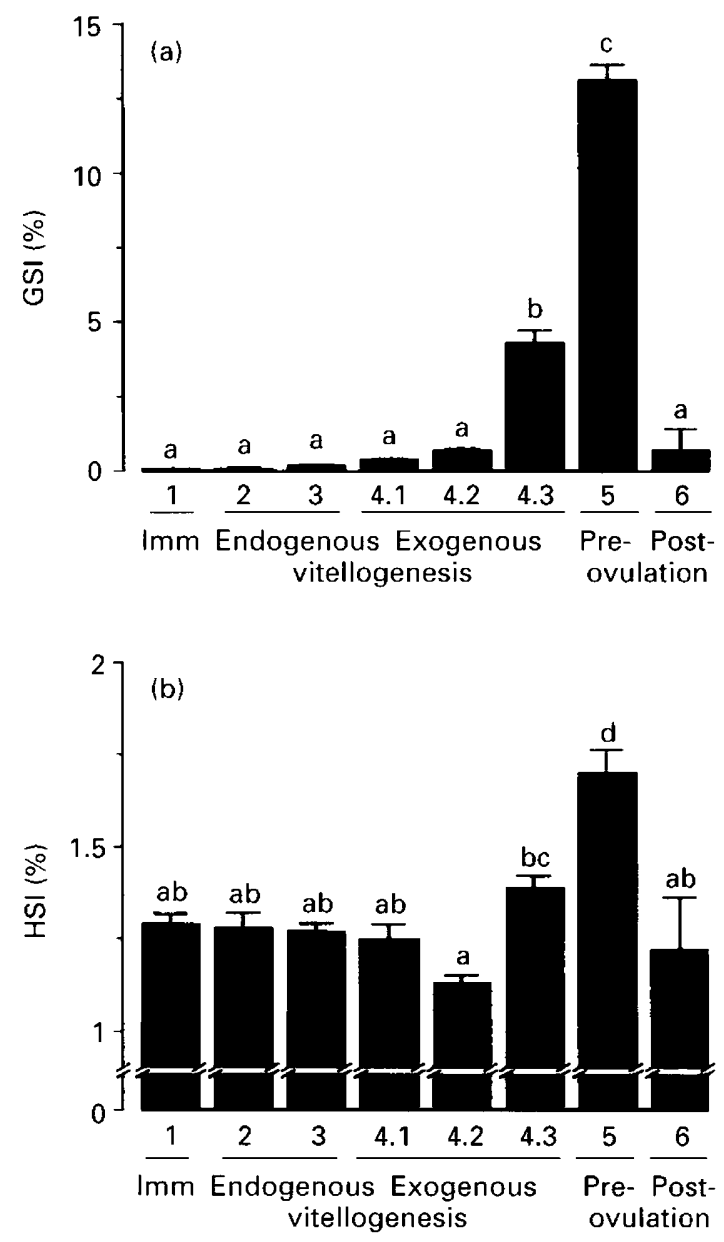

Fig. 4. Changes in (a) gonadosomatic index (GSI) and (b) hepatosomatic index (HSI) in rainbow trout during ovogenesis. Different letters above histograms represent significant differences (Kruskal-Wallis test). ANOVA, $P<0.001$. Results are expressed as the means + SEM for 22-83 fish, except for stage 6 of ovogenesis from which 14 fish were used. Imm, immature.

unchanged during the rest of the cycle. The absolute binding capacity of the whole gonad (Fig. 6) expressed in pmol per pair of gonads (or in pmol per pair of gonads $\mathrm{kg}^{-1}$ body weight, that is, normalized for body size; data not shown) was low from the immature stage to early exogenous vitellogenesis (0.1-0.6 pmol per pair of gonads), increased significantly during exogenous vitellogenesis (stage 4.1-4.3) and more markedly in the rapidly growing ovary and before ovulation (stage 5: $10.8 \mathrm{pmol}$ per pair of gonads). In postovulated fish, the absolute binding capacity was decreased ( 4.4 pmoles per pair of gonads).

\section{Changes of hepatic growth hormone receptors and plasma growth hormone during ovogenesis}

The characteristics of ${ }^{125}$ I-labelled rtGH binding to crude hepatic preparations obtained from rainbow trout at different stages were also determined (Table 1). Scatchard plot analyses of the data indicate the presence of a single population of binding sites during the entire ovogenetic cycle with unchanged high affinity $\left(4.9 \times 10^{9} \pm 0.1 \mathrm{~mol} \mathrm{l}^{-1}\right.$, $n=16$ ) for ${ }^{125}$ I-labelled $\mathrm{rtGH}$ and significant changes of binding capacity. Specific ${ }^{125} \mathrm{I}$-labelled $\mathrm{rtGH}$ binding to individual livers corresponding to the ovaries studied above was measured in single point binding studies (Fig. 7). Binding was constant during most of the cycle except during endogenous vitellogenesis (6.7 pmoles $\mathrm{g}^{-1}$ liver) where there was an increase. The GH-R concentration in liver, expressed in fmol $\mathrm{g}^{-1}$ tissue, appeared to be $20-80$-fold higher, according to the sexual stage (calculated with binding data), than GH-R concentration in ovary. The total binding capacity of the liver, expressed in fmol per liver $\mathrm{kg}^{-1}$ body weight (corrected for general body growth), showed similar changes to the hepatic GH-R concentration (data not shown).

The plasma concentrations of $\mathrm{GH}$ were low $\left(<1 \mathrm{ng} \mathrm{ml}^{-1}\right)$ and tended to decrease (non-significantly) during the entire reproductive cycle. The relationships among plasma $\mathrm{GH}, \mathrm{GH}$ binding in liver and GH binding in ovary were assessed by linear regression analysis of individual values. A significant correlation was found between ovarian GH-R concentration and hepatic GH-R concentration (expressed in fmol $\mathrm{g}^{-1}$ ovary: $r=0.5, \mathrm{P}=0.01$ or expressed in fmol $\mathrm{g}^{-1}$ pellet: $r=0.6$, $P=0.01$ ), while no relation was found between plasma $\mathrm{GH}$ concentration and GH-R concentration (ovarian GH-R concentration:plasma GH concentration: $r=-0.2$; hepatic GH-R concentration:plasma GH concentration: $r=-0.2$ ).

\section{Discussion}

This study describes a method that allows the measurement of $\mathrm{GH}$ receptors in individual ovaries at all stages of ovogenesis in rainbow trout. As has been described for crude testicular preparations (Gomez et al., 1998), crude ovarian preparations were chosen because they gave a less variable and a higher recovery yield of receptors than protocols using enriched membrane preparations. In protocols using enriched membrane preparations, changes in ovary composition during the reproductive cycle mainly due to vitellogenin incorporation influence the yield of membrane recovery and create technical variability among stages (data not shown). Furthermore, in mammals (Hocquette et al., 1989; Fraser and Harvey, 1992) and teleost fish (Yao, 1993), GH-R is localized preferentially in membranes associated with intracellular structures as well as plasma membranes of GH target cells, and a crude membrane preparation could be more representative of the tissue receptivity potential than purified plasma membrane preparations. Finally, this method allows the quantification of GH-R on small amounts of tissue and, therefore, on individual gonads at most stages of the ovarian cycle. Desaturation by $\mathrm{MgCl}_{2}$ treatment (Kelly et al., 1979) of the binding sites possibly occupied by endogenous GH was not applied to crude ovary preparation. However, the low concentration of plasma GH found at all stages of oogenesis indicates that the number of free binding sites estimated in this study was a good assessment of total number of binding sites.

The results of the present study revealed that the affinity and specificity of $\mathrm{GH}$ binding to crude ovarian homogenates 
Table 2. $K_{\mathrm{a}}$ and $B_{\max }$ values for ${ }^{125}$-labelled rtGH binding in ovary and liver during the first ovogenetic cycle in rainbow trout

\begin{tabular}{lcccccccc}
\hline & \multicolumn{7}{c}{ Stages } \\
\cline { 2 - 8 } & 1 & 2 & 3 & 4.1 & 4.2 & 4.3 & 5 & 6 \\
\hline Ovary & & & & & & & & \\
$K_{\mathrm{a}} \times 10^{9}\left(\mathrm{~mol}^{-1}\right)$ & $2.8 \pm 0.4$ & 3.2 & $4.3 \pm 0.4$ & $4.7 \pm 1.6$ & 3.0 & 6.7 & $5.2 \pm 0.7$ & $4.0 \pm 0.7$ \\
$B_{\max }\left(\mathrm{fmol} \mathrm{g}^{-1}\right.$ ovary) & $152 \pm 38$ & 183 & $200 \pm 14$ & $267 \pm 71$ & 43 & 54 & $35 \pm 1$ & $390 \pm 126$ \\
$n$ & 2 & 1 & 4 & 2 & 1 & 1 & 2 & 4 \\
Liver & & & & & & & & \\
$\quad K_{\text {a }} \times 10^{9}\left(\mathrm{~mol}^{-1}\right)$ & $4.7 \pm 0.1$ & $4.8 \pm 0.4$ & $4.9 \pm 0.4$ & $4.9 \pm 0.4$ & $5.4 \pm 0.5$ & $4.8 \pm 0.2$ & $5.1 \pm 0.1$ & $5.1 \pm 0.2$ \\
$B_{\max }\left(\mathrm{pmol} \mathrm{g}^{-1}\right.$ liver $)$ & $6.3 \pm 0.5$ & $4.6 \pm 0.2$ & $5.2 \pm 0.5$ & $3.5 \pm 0.2$ & $3.2 \pm 0.1$ & $1.9 \pm 0.3$ & $7.1 \pm 0.3$ & $5.3 \pm 2.8$ \\
$n$ & 2 & 2 & 2 & 2 & 2 & 2 & 2 & 2 \\
\hline
\end{tabular}

Pools of ovaries at the same ovogenetic stage (pools of 12-18 pairs of gonads from the immature stage to early endogenous vitellogenesis; pools of 3-12 pairs of gonads from endogenous vitellogenesis to ovulated fish) and livers corresponding to the same animals were used.

Results are expressed as mean \pm SEM; $n$, number of saturation experiments.
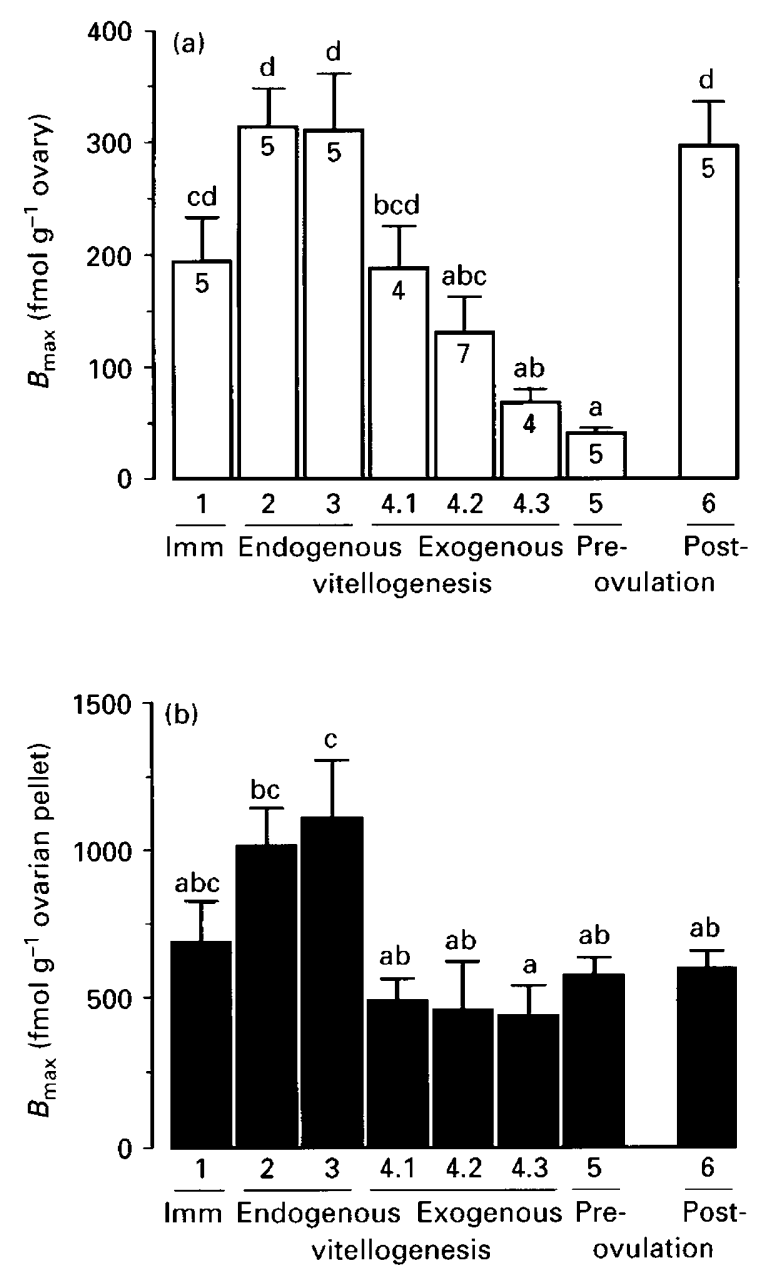

Fig. 5. Changes of GH receptor concentrations expressed in (a) fmol $\mathrm{g}^{-1}$ ovary or (b) fmol $\mathrm{g}^{-1}$ ovarian pellet in rainbow trout during ovogenesis. ${ }^{125} \mathrm{I}$-labelled recombinant trout $\mathrm{GH}$ (rtGH)-specific binding ( 300000 c.p.m. per tube) was performed with $20 \mathrm{mg}$ pellet per tube. Specific ${ }^{125}$ I-labelled $\mathrm{rtGH}$ binding was measured on individual gonads chosen at each stage of ovogenesis (except for were similar to those described in rainbow trout with crude hepatic preparations (Sakamoto and Hirano 1991; Yao et al., 1991), and with ovarian or hepatic membrane preparations (Le Gac et al., 1992; Mourot et al., 1992). The apparent $K_{\mathrm{a}}$ obtained in the present study was higher than those described in partially purified ovarian membrane (B. Mourot and $A$. Fostier, unpublished), owing probably to differences in tracer preparation and apparent specific activity. Binding was specific to $\mathrm{GH}$ with little or no affinity for other hormones tested. Previous studies in teleosts also found that prolactin does not bind to GH-R, indicating that GH and prolactin have distinct binding sites in fish (Yao et al., 1991; Auperin et al., 1994). $K_{\mathrm{a}}$ values were in the same range as those described in the testis (Gomez et al., 1998), central nervous system (Perez-Sanchez et al., 1991), gill (Sakamoto and Hirano, 1991) of the same species, and in the liver of other fish (Hirano, 1991; Mori et al., 1992). The apparent

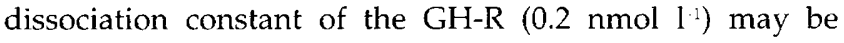
considered high compared with the plasma concentration measured in the present study $\left(0.03 \mathrm{nmol} \mathrm{1}^{-1}\right)$. However, plasma $\mathrm{GH}$ concentration in rainbow trout shows episodic fluctuations (Gomez et al., 1996) that can lead to transient high concentrations of $\mathrm{GH}$, which could bind efficiently to GH-R. Moreover, the expression of GH mRNA has been detected by PCR in testis (Untergasser et al., 1997), indicating that the local production of small amounts of $\mathrm{GH}$ is not impossible. However, it was not possible to show the expression of GH mRNA in rainbow trout testis by northern blot analysis (F. Le Gac, unpublished). The present study is in agreement with results in mammals revealing GH-R mRNA and immunoreactivity in the ovary.

In rainbow trout, ovarian GH-R concentration was highest during the first stages of maturation, and decreased regularly throughout exogenous vitellogenesis to reach a minimal value during the pre-ovulatory period. In contrast, in postovulated fish, GH-R concentration had returned to

immature stage (Imm) and final oocyte maturation from which pools of 3-6 pairs of gonads were used). Different letters above histograms represent significant differences (Kruskal-Wallis test). ANOVA, $P<0.001$. Results are expressed as means + SEM for $4-7$ values $(n$ given inside the bars in (a)). 


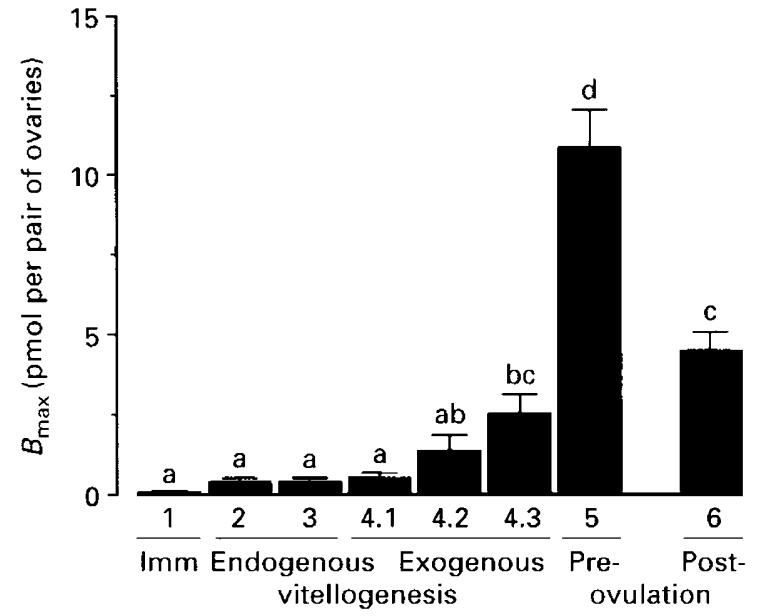

Fig. 6. Changes of $\mathrm{GH}$ receptor capacity (expressed in pmol per ovary) in rainbow trout ovary during ovogenesis. ${ }^{125} \mathrm{I}$-labelled recombinant trout $\mathrm{GH}$ (rtGH)-specific binding ( 300000 c.p.m. per tube) was performed with $20 \mathrm{mg}$ pellet per tube at all stages of ovogenesis. Specific ${ }^{125} \mathrm{I}$-labelled $\mathrm{rtGH}$ binding was measured on individual gonads chosen at each stage of ovogenesis (except for immature stage ( $\mathrm{Imm}$ ) and final oocyte maturation from which pools of 3-6 pairs of gonads were used). Different letters above histograms represent significant differences (Kruskal-Wallis test). ANOVA, $P<0.001$. Results are expressed as the means + SEM for 4-7 values.

concentrations similar to those observed in endogenous vitellogenesis. These changes in GH binding result from a progressive change in the GH-R capacity, with no alteration of their affinity. Attempts to quantify binding sites for $\mathrm{GH}$ in the ovary were unsuccessful in several vertebrates owing to the low ratio of specific:non-specific binding (Eckery et al., 1997). Only one developmental study showed that ovarian GH-R/BP mRNA expression decreases between 1 and 5 weeks of age in rats, and does not change during the oestrous cycle (Carlsson et al., 1993). The 6-7-fold decrease in GH-R concentration (pmol g-1 ovary) during the second part of the oogenetic cycle reflects the increase of oocyte size and yolk accumulation during vitellogenesis, which results in a 'dilution' of the cells or tissues bearing the receptors. In fact, when the same data were expressed in $\mathrm{fmol} \mathrm{g}^{-1}$ crude pellet (that is mainly exempt of yolk), GH binding was remarkably stable during vitellogenesis (stages 4.1-5). In trout, a large number of oocytes develop and ovulate synchronously in the entire gonad and, after ovulation, the ovarian tissue is mainly constituted of oogonia, primary oocytes, granulosa, luteal and theca cells as well as fibroblasts and blood vessels. The similar concentration of GH-R (pmol g-1 ovary) during endogenous vitellogenesis and in postovulatory stages indicates that $\mathrm{GH}$ receptors are localized primarily in ovarian somatic cell membranes rather than in maturing oocyte membranes. This finding is in accordance with the detection in mammals of GH-R/BP mRNA and immunoreactivity on granulosa and, sometimes, in theca cells. However, the possibility cannot be excluded that there is a low concentration of GH-R in oocyte membranes because studies have detected GH-R/BP mRNA in sheep and cow oocytes (Eckery et al., 1997; Izadyar et al., 1997).

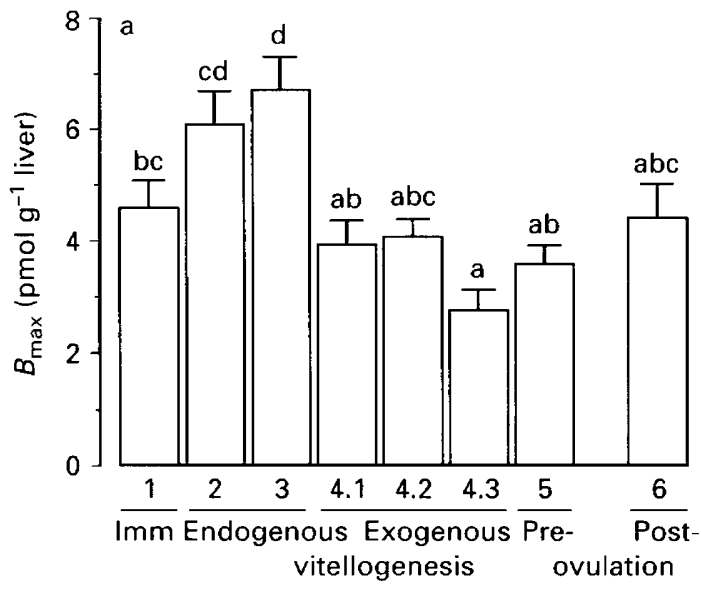

Fig. 7. Changes of $\mathrm{GH}$ receptor concentrations (expressed in pmol $\mathrm{g}^{-1}$ of liver) in rainbow trout during ovogenesis. ${ }^{125}$ I-labelled recombinant trout $\mathrm{GH}$ ( $\mathrm{rGH}$ )-specific binding (300000 c.p.m. per tube) was performed with $5 \mathrm{mg}$ pellet per tube. Specific ${ }^{125} \mathrm{I}$-labelled rtGH binding was measured on individual livers chosen at each stage of ovogenesis. Different letters above histograms represent significant differences (Kruskal-Wallis test). ANOVA, $P<0.001$. Results are expressed as means + SEM for 5-8values.

Although the roles and mechanisms of $\mathrm{GH}$ action in the ovary have not been elucidated, information has been obtained, particularly in domestic mammals. In brief, regulatory effects of $\mathrm{GH}$ on follicular growth and the number of follicles developing during an oestrous cycle have been documented in cows and ewes and GH enhances the response to superovulation treatments in women and domestic animals (Gong et al., 1991, 1993; Eckery et al., 1997). GH stimulates the development of early (preantral) follicles in vitro (Liu et al., 1998), it affects the maturation of cumulusenclosed bovine oocytes and may promote early embryonic development (Izadyar et al., 1996). Numerous GH effects on ovarian cells have been described, including the stimulation of granulosa cell proliferation, differentiation and steroidogenic activities, the increased production of insulin-like growth factors (IGFs) and modulation of IGFbinding proteins (Wathes et al., 1995; Sirotkin, 1996).

In the present study in trout, the highest GH-R concentrations (expressed in fmol $\mathrm{g}^{-1}$ ovary, fmol g-1 pellet or in fmol mg-1 protein) were observed in stages $2-3$ of ovarian development, when the oocytes are recruited to the vitellogenic process and start growing. This finding may indicate that the ovary is a target tissue for $\mathrm{GH}$ during this period. A hypothetical role of $\mathrm{GH}$ could be to adjust the number of growing oocytes depending on the general metabolic status of the animal. In fact, the influence of growth on fish fecundity has been suggested previously. GH could also enchance follicular growth and development in these early stages. In fish, GH may act by enhancing the gonadotrophic stimulation of ovarian steroidogenesis (Van Der Kraak et al., 1990) or could be effective alone on testosterone and oestradiol production as found using ovarian tissues in vitro or hypophysectomized female fish (Singh et al., 1988; Singh and Thomas, 1993). In another 
respect the highest total binding capacity for GH in trout ovary was found during the final stage of the cycle and in ovulated gonads, and a potential role for $\mathrm{GH}$ in final maturation and ovulation in fish must be considered. The increase in plasma GH concentrations at the end of the reproductive cycle was described in several species (for review, see Le Gac et al., 1993) and studies have shown that GnRH peptides (and sex steroids) play an important role in the regulation of growth hormone secretion in several teleosts, especially when undergoing gonadal development or in sexually mature fish (Peter and Marchant, 1995). Several authors have emphasized the possible 'gonadotrophic' function of GH. GH action may occur through the local production of IGF-I, as has been suggested in fish testis (Le Gac et al., 1996). In fact, IGF-I mRNA and IGF-I receptors are expressed in fish ovary (Guttierez et al., 1992; Duan et al., 1993) and IGF-I was found to act on final oocyte maturation (Kagawa et al., 1994) and to increase the ovarian production of oestradiol and of $17 \alpha, 20 \beta$-dihydroxy-4 pregnen-3-one (the meiosis inducing steroids in trout) (Maestro et al., 1995, 1997; Fostier et al., 1994). However, to our knowledge, no effect of GH on ovarian IGF production has been demonstrated (Duguay et al., 1994).

During the reproductive cycle, the hepatic GH-R concentration $\mathrm{g}^{-1}$ tissue increased significantly at the initiation of the ovarian cycle during endogenous vitellogenesis, and then decreased and remained at the same concentration for the rest of the oogenetic cycle. These changes differ from those observed in rodents, in which large and continuous increases of hepatic GH binding or GH-R mRNA have been described during sexual maturation (Maes et al., 1983; Mathews et al., 1989). However, these changes may be related to the rapid growth and to the metabolic status of the animals during puberty, rather than directly to their sexual status. The lower hepatic GH-R concentration observed in rainbow trout in stages 4.2 and 4.3 might be accounted for by temperature and nutritional effects since, at the time these fish were sampled, they had just been submitted to the increase in water temperature that occurs during summer, and to a reduced food ration at the end of summer administered to compensate for the higher temperature. Indeed, decreased liver GH-R has been shown to occur in the case of food restriction in teleost fish (Gray et al., 1992; Perez-Sanchez et al., 1994). The liver, which is the source of vitellogenin, a major component in yolk production, increases in size during rapid vitellogenesis. The total amount of binding sites per liver was found to be increased in fish killed at the end of this period. These fish presented morphological signs of final oocyte maturation (stage 5). Whether this increase is related to external factors, or is somehow related to vitellogenesis or final sexual maturation remains unclear.

The changes of ovarian GH-R concentration in comparison with hepatic GH-R and plasma GH concentrations were analysed. Changes in hepatic and ovarian GH-R concentration during the reproductive cycle showed similar general patterns and significant positive individual correlation. Such correlation indicates that GH-R in these two tissues may be subject to common regulatory factors. Such a hypothesis is not in agreement with the demonstration that the regulation of GH-R expression may be controlled by a tissue-specific mechanism (Frick et al., 1990; Ymer and Herington, 1992). In mammals, one speculation is that an alternative promoter controls GH-R expression in reproductive organs that are target tissues for placental somatotrophin or lactogen hormones (see Heap et al., 1996), but such a mechanism would not be relevant to the ovarian cycle in teleosts. On the other hand no correlation was found in male rainbow trout between liver and testis GH-R concentration during spermatogenesis (Gomez et al., 1998). Hepatic GH receptors are either up- or downregulated by plasma GH in mammals (for review, see Gluckman et al., 1989). In teleost fish, regulation of hepatic GH-R by high plasma GH has also been reported (Gray et al., 1990; Hirano, 1991; Mori et al., 1992). In the present study, variations in ovarian or hepatic GH receptors did not appear to be significantly correlated with changes in plasma $\mathrm{GH}$ concentration (in particular, the decrease in ovarian GH-R concentration observed during vitellogenesis cannot be attributed to downregulation or to binding sites occupied by endogenous $\mathrm{GH}$, as the amount of this hormone tended to decrease at this time). However, in the strain of rainbow trout observed in the present study, particularly low $\mathrm{GH}$ concentrations and small fluctuations of this hormone were probably not the best conditions for such an analysis. Luteinizing hormone (Juengel et al., 1997) and gonadal steroids (Baumbach and Bingham, 1995) were also proposed as powerful regulators of hepatic GH-R messenger. A possible relationship between oestradiol or gonadotrophin concentrations and $\mathrm{GH}-\mathrm{R}$ expression is under investigation.

Finally, factors such as water temperature and nutrition may affect GH-R in gonads as well as in the liver.

In conclusion, a method for the measurement of GHspecific binding in crude ovarian preparations has been validated in rainbow trout. The presence of $\mathrm{GH}$ receptors has been observed at all stages of ovogenesis, including in immature fish, but the highest GH-R concentration was observed during the initial step of ovarian growth and the total receptor capacity was maximal during final follicular maturation. The marked decrease in ovarian GH-R concentration during ovogenesis was found to be related to similar changes of hepatic GH-R but not to plasma GH concentration. The present data support the occurrence of GH-R mainly in somatic ovarian cells. In view of these results and of other data obtained in fish and mammals, it is suggested that $\mathrm{GH}$ has a gonadotrophic function during final maturation, but also that this hormone is potentially important for gonadal functions during the first steps of ovogenesis (recruitment in vitellogenesis and initiation of oocytes growth). It will be necessary to identify the cell types that express the GH receptor and to develop in vivo or in vitro experimental models to test the effects of $\mathrm{GH}$ treatments on oocyte recruitment, follicular growth or final maturation.

The authors are grateful to P. Y. Le Bail for access to hormone preparations and to homologous GH-RIA. They thank B. Breton and P. Prunet for the supply of fish hormones. They also thank J. Hall for help in revising the English of the manuscript. This work was supported by funds from the Institut National de la Recherche 
Agronomique and from the Region Bretagne (BRITTA). J. M Gomez received a fellowship from the Ministère de la Recherche et de l'Enseignement Supérieur.

\section{References}

Adashi EY, Resnick CE, Hurwitz A, Ricciarelli E, Hernandez ER, Roberts CT, Leroith D and Rosenfeld R (1992) The ovarian and testicular IGF-I system: a comparative analysis. In Spermatogenesis Fertilization Contraception pp 143-168 Eds E Nieschlag and U Habenicht. Springer-Verlag, Berlin

Advis JP, White SS and Ojeda SR (1981) Activation of growth hormone short loop negative feedback delays puberty in the female rat Endocrinology 108 1343-1352

Ando M, Yoshimura Y, Karube M, Ubukata Y, Nakamura Y, Iwashita M, Oda $T$ and Jinno $M$ (1994) Direct ovarian effect of growth hormone in the rabbit American Journal of Reproductive Immunology 31 123-132

Auperin B, Rentier-Delrue F, Martial JA and Prunet $P(1994)$ Characterization of a single prolactin (PRL) receptor in tilapia (Oreochromis niloticus) which binds both PRLI and PRLII Journal of Molecular Endocrinology 13 241-251

Baumbach WR and Bingham B (1995) One class of growth hormone receptor and binding protein messenger ribonucleic acid in rat liver, GHR1, is sexually dimorphic and regulated by GH Endocrinology 136 749-760

Bingham B, Oldham ER and Baumbach WR (1994) Regulation of growth hormone receptor and binding protein expression in domestic species Proceedings of the Society for Experimental Biology and Medicine 206 195-199

Breton B, Fostier A, Zohar Y, Le Bail P-Y and Billard R (1983) Gonadotropine glycoprotéique maturante et oestradiol- $17 \beta$ pendant le cycle reproducteur chez la truite fario (Salmo trutta) femelle General and Comparative Endocrinology $49220-231$

Burger HG, Kovacs GT, Polson DM, McDonald J, McCloud PI, Harrop M, Colman P and Healy DL (1991) Ovarian sensitization to gonadotrophins by human growth hormone: persistence of the effect beyond the treated cycle Clinical Endocrinology 35 119-122

Carlsson B, Bergh C, Bentham J, Olsson JH, Norman MR, Billig H, Roos P and Hillensjo $T$ (1992) Expression of functional growth hormone receptors in human granulosa cells Human Reproduction 7 1205-1209

Carlsson B, Nilsson A, Isaksson OGP and Billig H (1993) Growth hormonereceptor messenger RNA in the rat ovary: regulation and localization Molecular and Cellular Endocrinology 95 59-66

Duan C, Dugay SJ and Plisetskaya EM (1993) Insulin like growth factor I (IGF-I) mRNA expression in coho salmon Oncorhynchus kisutch: tissue distribution and effects of growth hormone/prolactin family protein Fish Physiology and Biochemistry 11 371-379

Duguay SJ, Swanson P and Dickhoff WW (1994) Differential expression and hormonal regulations of alternatively spliced IGF-I mRNA transcripts in salmon Journal of Molecular Endocrinology 12 25-37

Eckery DC, Moeller CL, Nett TM and Sawyer HR (1997) Localization and quantification of binding sites for follicle-stimulating hormone, luteinizing hormone, growth hormone, and insulin-like growth factor I in sheep ovarian follicles Biology of Reproduction 57 507-513

Fostier A, Le Gac F and Loir M (1994) Facteur de croissance de type insulinique et régulation gonadique chez les poissons Contraception Fertilité Sexualité 22 548-550

Fraser RA and Harvey S (1992) Ubiquitous distribution of growth hormone receptors and/or binding proteins in adenohypophyseal tissue Endocrinology 130 3593-3600

Frick GP, Leonard JL and Goodman HM (1990) Effect of hypophysectomy on growth hormone receptor gene expression in rat tissues Endocrinology 126 3076-3082

Gluckman PD and Breier BH (1989) The regulation of the growth hormone receptor. In Biotechnology in Growth Regulation pp 27-33 Eds RB Heap, CG Prosser and GE Lamming. Butterworths, London

Gomez JM, Boujard T, Fostier A and Le Bail P-Y (1996) Characterization of growth hormone nycthemeral plasma profiles in catheterized rainbow trout (Oncorhynchus mykiss) Journal of Experimental Zoology 274 171-180

Gomez JM, Loir M and Le Gac F (1998) Growth hormone receptors in testis and liver during the spermatogenetic cycle in rainbow trout (Oncorhynchus mykiss) Biology of Reproduction 58 483-491

Gong JG, Bramley T and Webb R (1991) The effect of recombinant bovine somatotropin on ovarian function in heifers: follicular populations and peripheral hormones Biology of Reproduction 45 941-949
Gong JG, Bramley TA, Wilmut I and Webb R (1993) Effect of recombinant bovine somatotropin on the superovulatory response to pregnant mare serum gonadotropin in heifers Biology of Reproduction 48 1141-1149

Govoroun MS, Huet JC, Pernollet JC and Breton B (1997) Use of immobilized metal ion affinity chromatography and dye-ligand chromatography for the separation and purification of rainbow trout pituitary gonadotrophins, GTH I and GTH Il Journal of Chromatography 698B 35-46

Gray ES, Young G and Bern HA (1990) Radioreceptor assay for growth hormone in coho salmon (Oncorhynchus kisutch) and its application to the study of stunting lournal of Experimental Zoology 256 290-296

Gray ES, Kelley KM, Law S, Tsai R, Young G and Bern HA (1992) Regulation of hepatic growth hormone receptors in coho salmon (Oncorhynchus kisutch) General and Comparative Endocrinology 88 243-252

Greenwood FC, Hunter WM and Glover JS (1963) The preparation of ${ }^{13.1} \mathrm{I}-$ labelled human $\mathrm{GH}$ of high specific radioactivity Biochemical Journal 89 114-123

Guidice LC (1992) Insulin-like growth factors and ovarian follicular development Endocrine Reviews 4 641-669

Gutierrez J, Parrizas M, Carneiro N, Maestro M and Planas J (1992) Insulin and IGF-1 receptors and tyrosine kinase activity in carp ovaries: changes with reproductive stage Fish Physiology and Biochemistry 11 247-254

Heap D, Collier RJ, Boyd CK and Lucy MC (1996) Expression of alternate growth hormone receptor messenger RNA in ovary and uterus of cattle Domestic Animal Endocrinology $13420-430$

Hirano T (1991) Hepatic receptors for homologous growth hormone in the eel General and Comparative Endocrinology 81 383-390

Hocquette JF, Postel-Vinay MC, Kayser C, de Hemptinne B and AmarCostesec A (1989) The human liver growth hormone receptor Endocrinology $1252167-2174$

Homburg R, West C, Torresani T and Jacobs HS (1990) A comparative study of single dose growth hormone therapy as an adjuvant to gonadotrophin treatment for ovulation induction Clinical Endocrinology 32 781-785

Hsu CJ and Hammond JM (1987) Concomitant effects of growth hormone on secretion of insulin like growth factor I and progesterone by cultured porcine granulosa cells Endocrinology 121 1343-1348

Hutchinson LA, Findlay JK and Herington AC (1988) Growth hormone and insulin-like growth factor-I accelerate PMSG-induced differentiation of granulosa cells Molecular and Cellular Endocrinology 55 61-69

Izadyar F, Colenbrander B and Bevers MM (1996) In vitro maturation of bovine oocytes in the presence of growth hormone accelerates nuclear maturation and promotes subsequent embryonic development Molecular Reproduction and Development 45 372-377

Izadyar F, Vantol HTA, Colenbrander B and Bevers MM (1997) Stimulatory effect of grow th hormone on in vitro maturation of bovine oocytes is exerted through cumulus cells and not mediated by IGF-I Molecular Reproduction and Development 47 175-180

Jacobs HS, Bouchard P, Conway GS, Homburg R, Lahlou N, Mason B, Ostergaard H and Owen EJ (1991) Role of growth hormone in infertility Hormone Research 36 61-65

Jalabert B (1976) In vitro oocyte maturation and ovulation in rainbow trout (Salmo gairdneri), northern pike (Esox lucius) and goldfish (Carassius auratus) Journal of the Fisheries Rescarch Board of Canada 33 974-988

Jia XC, Kalminjn J and Hsueh AJW (1986) Growth hormone enhances follicle stimulating hormone-induced differentiation of cultured rat granulosa cells Endocrinology 118 1401-1409

Juengel JL, Nett TM, Anthony RV and Niswender GD (1997) Effects of luteotrophic and luteolytic hormones on expression of the mRNA encoding insulin-like growth factor I and growth hormone receptor in the ovine corpus luteum Journal of Reproduction and Fertility 110 291-298

Kagawa H, Kobayashi M, Hasegawa Y and Aida K (1994) Insulin and insulinlike growth factors I and II induce final maturation of oocytes of red seabream, Pagrus major, in vitro. General and Comparative Endocrinology 95 293-300

Katz E, Ricciarelli E and Adashi EY (1993) The potential relevance of growth hormone to female reproductive physiology and pathophysiology Fertility and Sterility 59 8-34

Kelly PA, Leblanc G and Djiane J (1979) Estimation of total prolactin-binding sites after in vitro desaturation Endocrinology 104 1631-1638

Le Bail P-Y, Sumpter JP, Carragher JF, Mourot B, Niu PD and Weil C (1991) Development and validation of a highly sensitive radioimmunoassay for chinook salmon (Oncorhynchus tshawytscha) growth hormone General and Comparative Endocrinology 83 75-85

Le Gac F, Ollitrault M, Loir M and Le Bail P-Y (1992) Evidence for binding 
and action of growth hormone in trout testis Biology of Reproduction 46 949-957

Le Gac F, Blaise O, Fostier A, Le Bail P-Y, Loir M, Mourot B and Weil C (1993) Growth hormone (GH) and reproduction: a review Fish Physiology and Biochemistry 11 219-232

Le Gac F, Loir M, Le Bail P-Y and Ollitrault M (1996) Insulin-like growth factor (IGF-I) mRNA and IGF-I receptor in trout testis and in isolated spermatogenic and Sertoli cells Molecular Reproduction and Development 44 23-35

Liu X, Andoh K, Yokota H, Kobayashi J, Abe Y, Yamada K, Mizunuma $H$ and Ibuki $Y$ (1998) Effect of growth hormone, activin and follistatin on the development of preantral follicles from immature female mice Endocrinology $1392342-2347$

Lobie PE, Breipohl W, Aragon JG and Waters MJ (1990) Cellular localization of the growth hormone receptor/binding protein in the male and female reproductive systems Endocrinology 126 2214-2221

Lucy MC, Collier RJ, Kitchell ML, Dibner JJ, Hauser SD and Krivi GG (1993) Immunohistochemical and nucleic acid analysis of somatotropin receptor populations in the bovine ovary Biology of Reproduction 48 1219-1227

Maes M, De Hertogh R, Watrin-Granger P and Ketelslegers JM (1983) Ontogeny of liver somatotropic and lactogenic binding sites in male and female rats Endocrinology 113 1325-1331

Maestro MA, Planas JV, Gutierrez J, Moriyama S and Swanson P (1995) Effects of insulin-like growth factor I (IGF-I) on steroid production by isolated ovarian theca and granulosa layers of preovulatory coho salmon Netherland journal of Zoology 45 143-146

Maestro MA, Planas JV, Moriyama S, Gutierrez J, Planas J and Swanson P (1997) Ovarian receptors for insulin and insulin like growth factor-I (IGF I) and effects of IGF-I on steroid production by isolated follicular layers of the preovulatory coho salmon ovarian follicle General and Contparative Endocrinology 106 189-201

Martal J (1972) Détermination radioimmunologique des hormones de croissance ovine et bovine: étude des conditions d'iodation et obtention d'une hormone somatotrope radioiodée sans prolactine contaminante Comptes Rendus de l'Académie des Sciences 274 2893-2896

Mason HD, Martikainen H, Beard R, Anyaoku V and Franks S (1990) Direct gonadotrophic effect of growth hormone on estradiol production by human granulosa cells in vitro. Journal of Endocrinology 126 1-4

Mathews LS, Enberg B and Norstedt G (1989) Regulation of rat growth hormone receptor gene expression Journal of Biological Chemistry 264 9905-9910

Mercado M, Davila N, McLeod JF and Baumann G (1994) Distribution of growth hormone receptor messenger ribonucleic acid containing and lacking exon 3 in human tissues Journal of Clinical Endocrinology and Metabolism 78 731-735

Mertani HC, Delehaye-Zervas MC, Martini JF, Postel-Vinay MC and Morel G (1995) Localization of the growth hormone receptor messenger RNA in human tissues Endocrine 3 135-142

Mori I, Sakamoto T and Hirano T (1992) Growth hormone (GH)-dependent hepatic GH receptors in the Japanese eel Anguilla japonica: effects of hypophysectomy and $\mathrm{GH}$ injection General and Comparative Endocrinology 85 385-391

Mourot B, Fostier A, Yao K, Le Gac F and Le Bail P-Y (1992) Specific binding of salmonid growth hormone in rainbow trout (Oncorhynchus mykiss) ovary. In Proceedings of the 2nd International Symposium on Fish Endocrinology St Malo Abstract p 73

Ovesen P, Moller J and Moller N (1992) Growth hormone secretory capacity and serum insulin-like growth factor 1 levels in primary infertile, anovulatory women with regular menses Fertility and Sterility 57 97-101

Perez-Sanchez J, Smal J and Le Bail P-Y (1991) Location and characterization of growth hormone binding sites in the central nervous system of a teleost fish (Oncorhynchus mykiss) Growth Regulation $1145-152$

Perez-Sanchez J, Marti-Palanca H and Le Bail P-Y (1994) Homologous growth hormone (GH) binding in gilthead sea bream (Sparus aurata). Effect of fasting and refeeding on hepatic GH-binding and plasma somatomedinlike immunoreactivity Journal of Fish Biology 44 287-301

Peter RE and Marchant TA (1995) The endocrinology of growth in carp and related species Aquaculture 129 299-321
Prunet P and Houdebine LM (1984) Purification and biological characterization of chinook salmon prolactin General and Comparative Endocrinology 53 49-57

Ramaley JA and Phares CK (1980) Delay of puberty onset in female due to suppression of grow th hormone Endocrinology 106 1989-1993

Rentier-Delrue F, Swennen D, Prunet P, Lion M and Martial JA (1989) Tilapia prolactin: molecular cloning of two cDNAs and expression in Escherichia coli. DNA 8 261-270

Sakamoto T and Hirano T (1991) Growth hormone receptors in the liver and osmoregulatory organs of rainbow trout: characterization and dynamics during adaptation to seawater Journal of Endocrinology 130 425-433

Scatchard G (1949) The attraction of proteins for small molecules and ions Annals of the New York Academy of Sciences 51 660-673

Sharara FI and Nieman LK (1994) Identification and cellular localization of growth hormone receptor gene expression in the human ovary Journal of Clinical Endocrinology and Metabolism 79 670-672

Sheikholislam BM and Stempfel RS (1972) Hereditary isolated somatotropin deficiency: effects of human growth hormone administration Pediatrics 49 362-374

Singh H and Thomas P (1993) Mechanism of stimulatory action of growth hormone on ovarian steroidogenesis in spotted seatrout Cynoscion nebulosus. General and Comparative Endocrinology 89 341-353

Singh H, Griffith RW, Takahashi A, Kawauchi H, Thomas P and Stegeman JJ (1988) Regulation of gonadal steroidogenesis in Fundulus heteroclitus by recombinant salmon growth hormone and purified salmon prolactin General and Comparative Endocrinology 72 144-153

Sirotkin AV (1996) Direct action of growth hormone on bovine ovarian cells: effects on estradiol, oxytocin, vasopressin release by granulosa cells and on oocyte maturation and cleavage in vifro. Annals of Endocrinology 57 219-224

Tamura M, Sasano H, Suzuki T, Fukaya T, Watanabe T, Aoki H, Nagura H and Yajima A (1994) Immunohistochemical localization of growth hormone receptor in cyclic human ovaries Human Reproduction $92259-2262$

Tiong TS and Herington AC (1991) Tissue distribution, characterization, and regulation of messenger ribonucleic acid for growth hormone receptor and serum binding protein in the rat Endocrinology 129 1628-1634

Untergasser G, Kranewitter W, Schwarzler Madersbacher S, Dirnhofer S and Berger $\mathbf{P}$ (1997) Organ-specific expression pattern of the human growth hormone/placental lactogen gene-cluster in the testis Molecular and Cellular Endocrinology $13053-60$

Van Der Kraak, G Rosenbloom P and Peter RE (1990) Growth hormone dependent potentiation of gonadotrophin stimulated steroid production by ovarian follicles of the goldfish General and Comparative Endocrinology 79 233-239

Volpe A, Coukos G, Barreca A, Artini PG, Minuto F and Giordano G (1989) Ovarian response to combined growth hormone-gonadotrophin treatment in patients resistant to induction of superovulation Gynecological Endocrinology 3 125-133

Wathes DC, Perks CM ,Davis AJ and Denning-Kendall PA (1995) Regulation of insulin-like growth factor-I and progesterone synthesis by insulin and growth hormone in the ovine ovary Biology of Reproduction 53 882-889

Webb R, Gong JG and Bramley TA (1994) Role of growth hormone and intrafollicular peptides in follicle development in cattle Theriogenology $\mathbf{4 1}$ $25-30$

Yao K (1993) Caractérisation des récepteurs hépatiques de l'hormone de croissance (GH) chez la truite arc-en-ciel (Oncorhunchus mykiss) et étude préliminaire de leur régulation par le niveau d'alimentation et par la température PhD Thesis, University of Rennes

Yao K, Niu PD, Le Gac F and Le Bail P-Y (1991) Presence of GH specific binding sites in rainbow trout (Oncorhynchus mykiss) tissues: characterization of the hepatic receptor General and Comparative Endocrinology 81 72-82

Ymer SI and Herington AC (1992) Developmental expression of the growth hormone receptor gene in rabbit tissues Molecular and Cellular Endocrinology $8339-49$

Yuan W and Lucy MC (1996) Messenger ribonucleic acid expression for growth hormone receptor, luteinizing hormone receptor, and steroidogenic enzymes during the estrous cycle and pregnancy in porcine and bovine corpora lutea Domestic Animal Endocrinology 13 431-444 